\title{
An Investigation of the Students Opinion on the Use of Digital Storytelling in Learning English
}

\author{
Yentri Anggeraini \\ Universitas Baturaja \\ email: anggeraini.yentri@yahoo.com
}

\begin{abstract}
Various kinds of technology tools and media can be used to facilitate the leaching and learning English in this era. One of them is digital storytelling. It is a multimedia text including images, audio, or video accompanied by a narrated soundtrack to tell a story or give information. It combines the functions of visual, verbal, and audio those are important for language comprehension and skills. This present study aimed at investigating the students`opinions on the use of digital storytelling in EFL classroom. The questionnaire and interview were distributed to 31 participants as the main data. The results indicated that $84 \%$ students like learning English through digital storytelling, $81 \%$ of them enjoy presenting and sharing their digital literacy, and $77 \%$ of them argue that digital storytelling can motivate them to read a lot. It can be derived that digital storytelling makes the students participate actively during the learning process, allows the students to work collaboratively, and provide the students to be digitally literate.
\end{abstract}

Keywords: Digital teaching, digital storytelling, English learning

\section{INTRODUCTION}

Computer technology and internet access can be used by teachers and students as practical and useful tools to get better teaching and learning process. One of technology media that can be applied in EFL classroom is digital storytelling. (Anggeraini \& Afifah, 2017: Anggeraini, 2018). It is one ways of telling stories in the digital era through multimedia such as text, images, audio and video. Meanwhile, Robin (2011) defined digital storytelling simply as the activity of using digital tools to tell the stories. It derived as technology usage in education area. In addition, students who participate actively in the process of designing the digital stories develop their communication and language skills by learning to organize their ideas, ask questions, express opinions, and construct narratives. Students who get the opportunity to share their work with their classmates may also get new experience in analyzing their digital storytelling and other students' work, which can promote the emotional intelligence, collaborative and social learning (Robin, 2016). ShelbyCaffey, Úbéda , \& Jenkins (2014) mentioned that storytelling allows for the combining of traditional and new literacy practices in creating a highly creative end product. In addition, Abdel-Hack \& Helwa (2014) stated five categories of digital storytelling : Photo stories (the combination of images and text), video words (the combinations of words or phrases and 
picture to make a film or short clip/movie), presentations, staging, and video clip. Moreover, Condy et al (2012) indicated that digital storytelling enhanced the students understanding and respect for one another in the classroom. They listen and pay attention to the story from their classmates.

Some studies found that digital storytelling gave effect to students` English skills such as (Yamac \& Ulusoy , 2016: Bumgarner,2012) for the writing skill improvement, Anggeraini \&Nurul (2017) for the reading comprehension of the short stories, Cigerci \& Gultekin (2018) for developing listening comprehension skills, and James et al (2019) for enhancing speaking skills. In this study, the writer focused on the investigation of students opinion on the use of digital storytelling in learning English. Hopefully, the result of this study can be used as the reflection and evaluation for EFL teachers in implementing the digital storytelling in digital era.

\section{METHOD}

In order to get the data on the students opinion on the use of digital storytelling during their English classroom, there were some steps: preparing the research instruments (questionnaire and interview). Both instruments were validated by expert judgments. The sources instruments form were taken from Robin, 2011, Pelinet al, 2011, Anggeraini \& Afifah, 2017. Next, the writer selected the 31 senior high school students whom have ever joined English class by using digital storytelling. Then, the writer delivered the questionnaire sheet and in other day, the writer interviewed 5 students randomly.
The last step was analyzing the data and concluding the result of the study.

\section{FINDINGS AND DISCUSSION}

The Result Questionnaire of Students` Opinion the Use of Digital Storytelling in English Classroom

\section{Section I}

Chart 1. The Functions of Digital Storytelling in English Classroom

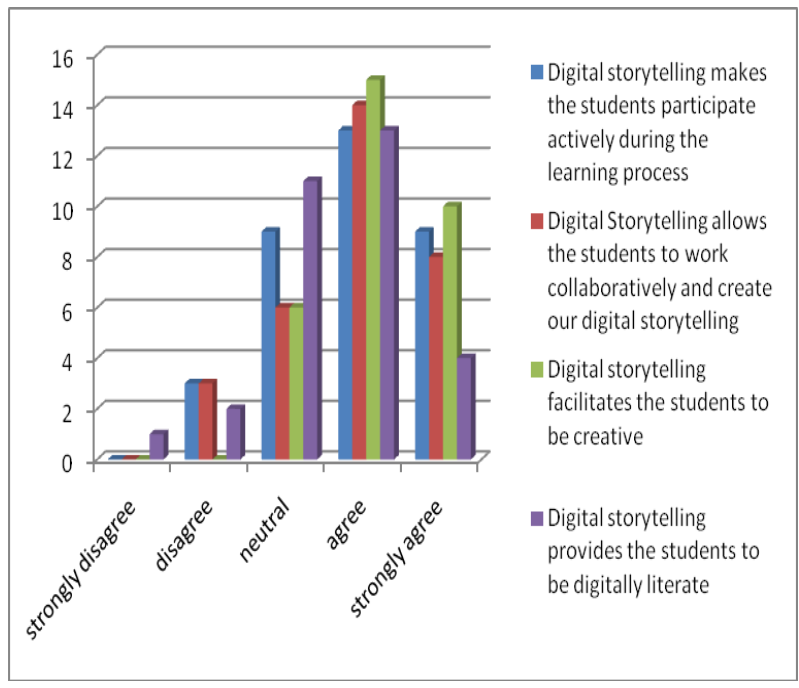

Chart 1 indicated that 3 of 31 students were disagree, 7 of them were neutral, 12 of them were agree, and 9 of them were strongly agree that digital storytelling makes the students participate actively during the learning process. In addition, 3 of 31 were disagree, 6 of them were neutral, 14 of them were agree, and 8 of them were strongly agree that digital storytelling allows the students to work collaboratively and create their digital storytelling. Next, 6 of 31 students were neutral, 15 of them were agree, and 10 of them were strongly agree that digital storytelling facilitates the students to be creative. The last, 1 of 31 students was strongly disagree, 2 of them 
were disagree, 11 of them were neutral, 14 of them were agree, and 4 of them were strongly agree that digital storytelling provides the students to be digitally literate.

\section{Section II}

Table 1. Digital Storytelling in Learning English

\begin{tabular}{|c|c|c|}
\hline Statement(s) & Yes & No \\
\hline $\begin{array}{l}\text { I like learning } \\
\text { through } \\
\text { storytelling }\end{array}$ & $\begin{array}{c}26 \\
84 \%\end{array}$ & $\begin{array}{c}5 \\
16 \%\end{array}$ \\
\hline $\begin{array}{l}\text { I enjoy creating the } \\
\text { digital storytelling }\end{array}$ & $\begin{array}{c}25 \\
81 \%\end{array}$ & $\begin{array}{c}6 \\
19 \%\end{array}$ \\
\hline $\begin{array}{l}\text { I enjoy presenting and } \\
\text { sharing my digital } \\
\text { storytelling to the others }\end{array}$ & $\begin{array}{c}20 \\
65 \%\end{array}$ & $\begin{array}{c}11 \\
35 \%\end{array}$ \\
\hline $\begin{array}{l}\text { Digital storytelling helps } \\
\text { to improve the listening } \\
\text { skill }\end{array}$ & $\begin{array}{c}14 \\
45 \%\end{array}$ & $\begin{array}{c}17 \\
55 \%\end{array}$ \\
\hline $\begin{array}{l}\text { Digital storytelling helps } \\
\text { to improve the speaking } \\
\text { skill }\end{array}$ & $\begin{array}{c}18 \\
58 \%\end{array}$ & $\begin{array}{c}13 \\
42 \%\end{array}$ \\
\hline $\begin{array}{l}\text { Digital storytelling } \\
\text { motivates me to read a lot } \\
\text { because it uses images, } \\
\text { texts, and sounds }\end{array}$ & $\begin{array}{c}24 \\
77 \%\end{array}$ & $\begin{array}{c}7 \\
23 \%\end{array}$ \\
\hline
\end{tabular}

Table 1 indicated that from 31 students, 845 of them like learning English through digital storytelling, $81 \%$ of them enjoy creating the digital storytelling, $65 \%$ of them enjoy presenting and sharing my digital storytelling to the others, $45 \%$ of them argue that digital storytelling helps to improve their listening skill, $58 \%$ of them argue that digital storytelling helps to improve their speaking skill, and $77 \%$ of the students argue that digital storytelling motivates them to read a lot because it uses images, texts, and sound to deliver the story.

\section{The Result of Interview Digital Storytelling to Promote English skill}

On the use digital storytelling in the classroom, the students to listen to video clip of digital storytelling, read, write their own, present to the classmates for the oral performance.

Student 1 explained :

"Digital Storytelling is an interesting way to learn English. It makes me easy to gap the story and the main point of the text"

Students 2 explained:

"I like learning English through digital storytelling because it provided simple word and music. I enjoy it. For my presentation of digital storytelling, I used photo series"

Students 3 explained:

"We should listen and read carefully the instruction from the digital storytelling so that we can answer the question from the teacher"

Students 4 explained:

"When I learn English by using digital storytelling, I get some new vocabulary and get new information from it"

Students 5 explained:

"In this class, I create digital storytelling through pictures series, sound and texts. I write the text and then present it in front of the class"

The findings revealed that the digital storytelling can motivate the students to read more and effect to their reading comprehension in line with Anggeraini \& Afifah (2014) developed the digital storytelling for teaching reading and it gave 
significant impact to the students in comprehending the text of short stories because in that activity allowed the students to explore and intpret the stories into their daily life and taking the moral value. Form the interview result indicated that digital storytelling makes the students easy to gap the main point of the story, the instruction from the digital storytelling makes them can answer the questions from the teacher, and the digital storytelling encourages them to get new vocabulary and information.

\section{CONCLUSION}

Digital storytelling can be used to empower English learners to create their stories that demonstrate knowledge and understanding of educational themes and concepts. They can also present/retell their digital storytelling to the others. From the students opinion on the use of digital storytelling in English classroom, it indicated that digital storytelling encourages students to collaborate with each other, encourages creativity and critical thinking, promotes digital literacy, increases vocabulary, and motivates the students to read a lot.

\section{REFERENCES}

Abdel-Hack, E.M., \& Helwa, H.S.A.A. (2014). Using Digital Storytelling and Weblogs Instruction to Enhance EFL Narrative Writing and Critical Thinking Skills among EFL Majors at Faculty of Education. International Research Journal, 5(1), 8-41.

Anggeraini, Y. (2018). Interactive Teaching: Activities and the Use of Technology in EFL Classroom. Language Circle: Journal of Language and Literature, 13(1).

Anggeraini, Y., \& Afifah, N. (2017). Digital Storytelling as a Teaching Medium in Reading Classroom. Language Circle: Journal of Language and Literature, 12(1), 8390.

Bumgarner, B.L. (2012). Digital storytelling in writing: A case study of student teacher attitudes toward teaching with technology (Doctoral Dissertation).

Cigerci, F.M., \& Gultekin, M. (2017). Use of Digital Stories to Develop Listening Comprehension Skills. Issues in Educational Research, 27(2), 252-268.

Condy, J et al. (2012). Pre-service Students` Perceptions and Experiences of Digital Storytelling in Diverse Classrooms. TOJET: The Turkish Online Journal of Educational Technology, 11(3), 278-285.

James, P. R. A. P., Yong, K. L., \& Yunus, M. M. (2019). Hear Me Out! Digital Storytelling to Enhance Speaking Skills. International Journal of Academic Research in Business and Social Sciences, 9(2), 190-202. 
Pelin et al. (2011). Educational Uses of ,Digital Storytelling around the World. Middle East: Technical University.

Robin, B. (2011). The educational uses of digital storytelling website. Retrieved from http://digitalstorytelling.coe.uh.edu

Robin, B.R. (2016). The Power of Digital Storytelling to Support Teaching and Learning. Digital Education Review,30,17-29.

Shelby-Caffey, C., Úbéda, E., \& Jenkins, B. (2014). Digital Storytelling Revisited: An Educator's Use of an Innovative Literacy Practice. Reading Teacher, 68(3),191-199.

https://doi.org/10.1002/trtr.1273

Smeda.

Yamac, A., \& Ulusoy, M. (2016). The Effect of Digital Storytelling in Improving the Third Graders`Writing Skills. International Electric Journal of Elementary Education,9(1),59-86. 